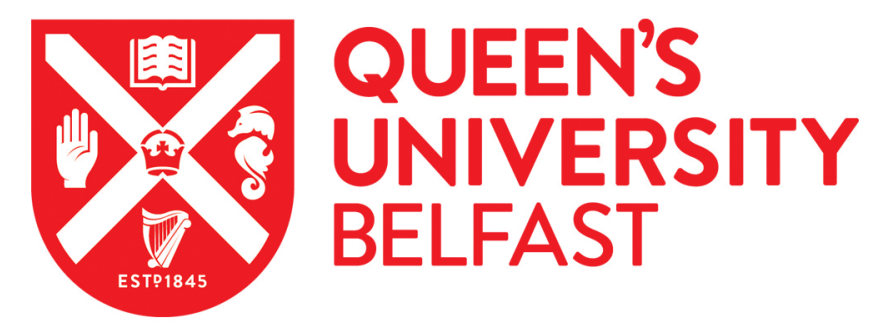

\title{
Source Identification of Trace Elements in Peri-urban Soils in Eastern China
}

Sun, L., Carey, M., Yang, L., Chen, L. D., Li, S. J., Zhao, F. K., Zhu, Y. G., Meharg, C., \& Meharg, A. A. (2018). Source Identification of Trace Elements in Peri-urban Soils in Eastern China. Exposure and Health. https://doi.org/10.1007/s12403-018-0290-1

\section{Published in:}

Exposure and Health

\section{Document Version:}

Peer reviewed version

Queen's University Belfast - Research Portal:

Link to publication record in Queen's University Belfast Research Portal

\section{Publisher rights}

(C) Springer Nature B.V. 2018.

This work is made available online in accordance with the publisher's policies. Please refer to any applicable terms of use of the publisher.

\section{General rights}

Copyright for the publications made accessible via the Queen's University Belfast Research Portal is retained by the author(s) and / or other copyright owners and it is a condition of accessing these publications that users recognise and abide by the legal requirements associated with these rights.

Take down policy

The Research Portal is Queen's institutional repository that provides access to Queen's research output. Every effort has been made to ensure that content in the Research Portal does not infringe any person's rights, or applicable UK laws. If you discover content in the Research Portal that you believe breaches copyright or violates any law, please contact openaccess@qub.ac.uk. 
Source identification of trace elements in peri-urban soils in eastern China

Long Sun ${ }^{1}$, Manus Carey ${ }^{2}$, Lei Yang ${ }^{*}$, Li-Ding Chen ${ }^{1,3}$, Shou-Juan Li ${ }^{1,3}$, Fang-Kai Zhao ${ }^{1,3}$, Yong-Guan Zhu' ${ }^{1,4}$, Caroline Meharg ${ }^{2}$, Andrew A. Meharg ${ }^{2 *}$

1 State Key Laboratory of Urban and Regional Ecology, Research Center for Eco-

Environmental Sciences, Chinese Academy of Sciences, Beijing 100085, China

2 Institute for Global Food Security, Queen's University Belfast, David Keir Building, Malone Road, Belfast, BT9 5AG, UK

3 University of Chinese Academy of Sciences, Beijing 100049, China

4 Key Laboratory of Urban Environment and Health, Institute of Urban Environment,

Chinese Academy of Sciences, Xiamen 361021, China

*Corresponding author: leiyang@rcees.ac.cn (Lei Yang); aa.meharg@qub.ac.uk (Andrew A. Meharg) 


\section{$1 \quad$ Abstract}

2 The source identification of trace elements in peri-urban soils have not been fully explored, 3 especially for the areas in eastern China. Here, 80 soil samples, including 40 from cropland, 11 4 from orchards and 29 from forests, were collected in a typical peri-urban catchment, Ningbo, 5 eastern China. The concentrations of arsenic (As), cadmium $(\mathrm{Cd})$, chromium $(\mathrm{Cr})$, copper $(\mathrm{Cu})$, 6 nickel $(\mathrm{Ni})$, lead $(\mathrm{Pb})$ and zinc $(\mathrm{Zn}), \mathrm{Pb}$ isotopes and basic soil properties were measured for 7 each soil sample. Multivariate analysis of correlation, regression, principal component analysis 8 (PCA) and isotopic tracers were used. The results showed that the trace elements concentrations 9 significantly differed in land uses, especially for $\mathrm{Cd}, \mathrm{Cu}$ and $\mathrm{Zn}$. For the 7 trace elements, the $10 \mathrm{Cd}, \mathrm{Cu}$ and $\mathrm{Zn}$ in crop soils are contaminant elements. In the peri-urban soils, $\mathrm{Cr}$ and $\mathrm{Ni}$ are 11 dominated by parent material and paedogenic processes. Difference in $\mathrm{As}$ and $\mathrm{Pb}$ concentrations between land uses maybe attributed to atmospheric deposition induced by fossil fuel combustion. Application of fertilisers, calcium phosphate and calcium superphosphate,

14 livestock manure and compost, are the dominant source of pollutants in peri-urban soils, 15 especially for $\mathrm{Cd}, \mathrm{Cu}$ and $\mathrm{Zn}$, indicating the key point for pollution control for this area. 16 Calcium and $\mathrm{P}$ are effective indicators of $\mathrm{Cd}, \mathrm{Cu}$ and $\mathrm{Zn}$ contamination for the peri-urban 17 catchment.

18 Key words: trace elements sources; peri-urban soil; land use; multivariate analysis 


\section{Introduction}

Peri-urban ecosystems serve at the transitional zone between urban and rural ecosystems

(Chen et al., 2008b; Huang et al., 2009; Simon, 2008; Zhu et al., 2017b). With the rapid urban

expansion and industrial development, the peri-urban areas are often the sites responsible both for food, materials and energy supplements and for urban and industrial waste disposal (Chen et al., 2008b; Khai et al., 2007; Xiang et al., 2018; Zheng et al., 2018; Zhu et al., 2017b). The associated fertiliser use, fossil fuel combustion and other related anthropogenic activities may exacerbate the trace element pollution in peri-urban soils (Chen et al., 2008b; Wei and Yang, 2010). Research into the source identification of trace elements will benefit for pollution control (Morton-Bermea et al., 2009; Ungureanu et al., 2017; Wei and Yang, 2010).

Trace elements are introduced naturally into soil through the weathering of parent materials, and can also result from a variety of human activities such as industrial and traffic emission (fossil fuel combustion), mining, smelting, manure and inorganic fertilizers application, road dust and waste disposal (Alloway, 2013; Ravankhah et al., 2017; Teng et al., 2014; Ungureanu et al., 2017; Wong et al., 2002). The soil parent materials and paedogenic processes generally have significant influences on elements of As, Co, Cr, Ni, Zn (Facchinelli et al., 2001; Guagliardi et al., 2013; Sun et al., 2013; Xu et al., 2014). Anthropogenic activities usually contribute the enrichment of As, Cd, Cu, Hg, Pb, Zn (Alloway, 2013; Lu et al., 2012; Manta et al., 2002; Nicholson et al., 2003; Sun et al., 2013; Xu et al., 2014). Anthropogenically derived trace elements have been found to accumulate in topsoil, and can lead to damage animal and human physiological functions via the food chain (Chen et al., 2008b; Fu et al., 2007; Hernandez et al., 2003; Rodriguez Martin et al., 2006; Tóth et al., 2016).

Trace element sources to soil differ by land use, due to differences in management activities, leading to differing contamination profiles (Chen et al., 2005b; Ettler et al., 2014; Liu et al., 2005; Micó et al., 2006; Sheppard et al., 2000; Teng et al., 2014). In ecosystems for which 
agricultural practices are intensive, trace elements sources include application of liquid and solid manure (or their derivatives, compost or sludge) or inorganic fertilisers (Alloway, 2013; Gimeno-García et al., 1996; Rodriguez Martin et al., 2006; Xiang et al., 2018). Trace elements in urban soils receive significant loads of contaminants from traffic and industrial activities, and pose a significant challenge to food production in such habitats (Madrid et al., 2002; Meharg, 2016; Teng et al., 2014). In addition, industrial development may contribute significant atmospheric pollutant deposition to soils (Chen et al., 2008a; De Vries et al., 2003; Duan and Tan, 2013; Hernandez et al., 2003; Zheng et al., 2004). However, studies on source identification of trace elements in peri-urban soils usually focused only on the vegetable fields (Chen et al., 2008b; Singh and Kumar, 2006) or mapping spatial distribution of the whole area

(de la Cueva et al., 2014; Guagliardi et al., 2013). Therefore, it is essential to identify the differences in concentrations and sources of trace elements for different land uses in peri-urban area.

Soil pollution by trace elements poses severe challenges to soil health and sustainability in China (Chen et al., 2015; Cheng and Hu, 2010; Cheng, 2003; Li et al., 2014; Liu et al., 2010). In China, the peri-urban zone begins beyond the contiguous built-up urban area and can extend as far as $300 \mathrm{~km}$ in the case of Chinese coastal cities (Webster and Muller, 2002). For example, the Hangzhou-Ningbo Corridor typifies the long-running and dynamic peri-urbanisation process in the Lower Yangtze Region of eastern China as a whole, arguably the world's largest extended urban region (Webster and Muller, 2002). Importantly, the huge pressure on food supply induced by rapid urbanisation process in the peri-urban area in eastern China has continued for decades (Chen et al., 2008b; Wei and Yang, 2010), we hypothesise that this will lead to distinctive contamination of agricultural soils within this catchment. This current study presents the results of soil trace elements in a peri-urban area in Ningbo city in eastern China. The objectives of this study were (1) to characterise differences in the concentrations of trace 
elements for different land uses; and (2) to identify the sources of trace elements in peri-urban areas of eastern China.

\section{Materials and methods}

\subsection{Site description}

The Zhangxi catchment (an area of $85 \mathrm{~km}^{2}$ and elevation range of 3-763 $\mathrm{m}$ ), a typical periurban area in Ningbo City, was selected as the study area. Ningbo is a coastal city in eastern China that has undergone rapid urbanisation processes in recent decades. The soil layer in the catchment is shallow (ca. $30 \mathrm{~cm}$ on average) and is dominated by a silt loam in the $0-20 \mathrm{~cm}$ soil layer and sandy loam in the $20-30 \mathrm{~cm}$ soil layer. The parental materials/bedrocks are mainly silicate and aluminosilicate rocks, carbonate and aluminosilicate clastic rocks. The region has a moderate subtropical monsoon climate, warm and humid during April to September, and the rainy season is around June. The catchment has an annual mean temperature of $17^{\circ} \mathrm{C}$ and mean annual precipitation of $1460 \mathrm{~mm}$. The Zhangxi is a mixed land use catchment, including forest (mainly natural secondary forest) and farmlands (crop, orchard, etc). The cropland is usually treated with manure and inorganic fertilisers in the winter, and the manure are mainly derived from humans and their domestic livestock including pigs and chickens (Xiang et al., 2018; Zheng et al., 2018). Fritillaria, peanut, rice and several types of vegetables are the main crops in study area. The crop rotation patterns include vegetable-vegetable rotation, crop-vegetable rotation and crop-crop rotation.

\subsection{Sample preparation and analysis}

Eighty representative sites were selected covering the two types of land use (farmlands and forest). Soil samples ( 0 to $20 \mathrm{~cm}$ ) were collected in March 2016, including $40 \mathrm{crop}, 11$ orchard and 29 forest soils (Fig. 1). Each sample comprised a mixture of five sub-samples randomly 
94 obtained in a $2 \mathrm{~m}^{2}$ grid. All soil samples were collected with a stainless hand auger and stored in snap-sealed polypropylene bags. Soil samples were dried in a Christ LD freeze dryer, sieved and milled (except for $\mathrm{pH}$ and soil texture determination) by hand to a fine powder in a mortar and pestle.

The concentrations of $\mathrm{As}, \mathrm{Cd}, \mathrm{Cr}, \mathrm{Cu}, \mathrm{Ni}, \mathrm{P}, \mathrm{Pb}$, and lead isotope ratios, were determined with the ICP-MS (Thermo Scientific iCAP Q) in direct solution acquisition mode using a Cetac ASX-520 Auto Sampler. The concentrations of Zn, Ca and K were determined with an X-ray fluorescence (Rigaku Nex CG bentchtop XRF). For ICP-MS analysis, BDH Prolabo Aristar 69\% nitric acid and BDH Prolabo Analar Normapur 30\% hydrogen peroxide were used for extraction/digestion. Eight standards were made up including one blank also containing internal standard. Results were calculated from the resulting calibration curve based on the average intensity from 3 replicates of each sample, blank and standard. The XRF analysis was performed in batches of 9 ( 8 samples and one certified reference material) with analysis lasting approximately 13 minutes per sample. Certified reference materials for ISE-921 (river clay) and blank sample are used for quality control and recovery analysis. The recovery rates for elemental contents were between 79 and $110 \%$ (Table S1).

The soil samples were also analysed for $\mathrm{Pb}$ isotopic composition to detect the input of anthropogenic $\mathrm{Pb}$. The nitric acid digestion procedure was used as the sample preparation and using the same ICP-MS for analysis. Five standards were made up including one blank. Certified lead isotope standard VHG-LISPB1-50 in 1\% $\mathrm{HNO}_{3}$ (LGC Standards) was used to make up all standards. Analysis of the samples was carried out using ICP-MS (Thermo Scientific iCap Q) which was connected to the auto-sampler. ${ }^{206} \mathrm{~Pb},{ }^{207} \mathrm{~Pb}$ and ${ }^{208} \mathrm{~Pb}$ were acquired at dwell times of $300 \mathrm{~ms}$ each. The measured ratios of ${ }^{206} \mathrm{~Pb} /{ }^{207} \mathrm{~Pb}$ and ${ }^{208} \mathrm{~Pb} /{ }^{207}$ were calculated from the resultant data based on the average intensity from 10 replicates of each sample, blank and standard, and then $\mathrm{Pb}$ ratios of individual sample were corrected using 
bracketing certified Pb isotopic standards (LGC Standards-VHG-LISPB1-50).

Soil samples for $\mathrm{pH}$ and soil texture were sieved to pass a $2 \mathrm{~mm}$ mesh. The soil $\mathrm{pH}$ was measured in water (1:2.5 soil:water ratio, w/v) using a pH-meter (Mettler Toledo Delta 320) (Imperato et al., 2003). The soil texture was determined with a laser diffraction particle size analyser (Malvern Mastersizer 2000) (Sun et al., 2013). The soil organic matter (SOM) was calculated by soil organic carbon which was measured by dichromate oxidation (Yeomans and Bremner, 1988). The $\mathrm{C} / \mathrm{N}$ ratio was determined with an elemental analyser (Elementar Vario EL III).

\subsection{Statistical analysis}

The Kolmogrov-Smirnov test was used to determine the normality of the metal concentrations. Differences in trace element concentrations among various types of land use were determined with non-parametric Kruskal-Wallis tests and ANOVA by a Tukey test. Principal component analysis (PCA) was used to cluster trace elements that showed similar behaviour to identify potential sources. Varimax rotation was applied because orthogonal rotation minimises the number of variables with a high loading on each component and facilitates interpretation of results (Sun et al., 2013). Correlation matrix and regression analysis were used to investigate elemental associations amongst the trace elements in the topsoil. For correlation analysis, Pearson's product moment correlation coefficient was used for normal populations, and Spearman's rank correlation coefficient was used for non-normal populations (Micó et al., 2006). Statistical tests were considered to indicate statistical significance at a $p$ level of less than 0.05. Outliers are not excluded during all data analysis except for the linear regression of $\mathrm{Pb}$ isotopes. All statistical analyses were performed in IBM SPSS Statistics 23.0.

\section{Results and discussion}




\subsection{Elemental concentrations and soil properties}

Descriptive statistics of the concentrations of elements, $\mathrm{Pb}$ isotopes and soil properties are summarised in Table 1. Soils could be classified as silt loam based on their clay, silt and sand contents. Only sand and silt had normal distributions, which was basically consistent with the general knowledge that soil properties are normally distributed with small coefficients of variation (Madrid et al., 2002; Sun et al., 2013). The soil pH values ranged from 4.0 to 6.9. Most soils were acidic; $51 \%$ had $\mathrm{pH}$ values below $\mathrm{pH}$ 5.0, and only $13 \%$ had $\mathrm{pH}$ values above $\mathrm{pH}$ 6.0. The acidic $\mathrm{pH}$ was partly due to the climate, the parent material and the soil texture (Barton et al., 1994) and partly due to the frequent use of mineral fertilisers (especially $\mathrm{N}$ fertiliser) and infrequent addition of fresh organic matter (Sun et al., 2013). For example, it has been reported that soil acidification in China results mainly from high inputs of $\mathrm{N}$ fertiliser and the uptake and removal of base cations by plants (Guo et al., 2010). The SOM had a large range, 11 to $172 \mathrm{~g} \mathrm{~kg}^{-1}$, with a mean value of $47 \mathrm{~g} \mathrm{~kg}^{-1}$. The high levels of SOM imply an important retention of trace elements by porous carbon with a high adsorption capacity (Micó et al., 2006; Oh and Park, 2002). However, the low clay content may decrease retention, and the acidic $\mathrm{pH}$ could also facilitate the mobility, of trace elements (Sun et al., 2013). The K concentration (23.3 $\left.\mathrm{g} \mathrm{kg}^{-1}\right)$ was similar with the background value of Ningbo $\left(23.0 \mathrm{~g} \mathrm{~kg}^{-1}\right)$ (Dong et al., 2007). The mean concentrations of $\mathrm{Ca}$ and $\mathrm{P}$ for soils were 2.0 and 1.5 times higher than the background values of Ningbo (2.3 $\mathrm{g} \mathrm{kg}^{-1}$ and $0.63 \mathrm{~g} \mathrm{~kg}^{-1}$ ) (Dong et al., 2007). Calcium and P are commonly used to improve plant growth and yield, and $\mathrm{Ca}$ is also commonly applied as lime to raise the $\mathrm{pH}$ of acidic soils (Alloway, 2013). Compared with the background values of Ningbo, the significantly high concentrations of $\mathrm{Ca}$ and $\mathrm{P}$ indicate extensive application of inorganic fertilisers, such as calcium phosphate and calcium superphosphate (Dong et al., 2007).

Data from forests and orchards were combined for further analysis because no significant differences in trace element concentrations were found between them (Fig. 2). In forest and 
orchard soils, the coefficients of variation for trace element concentrations varied from $32 \%$ for As to $100 \%$ for $\mathrm{Cr}$ and decreased in the order $\mathrm{Cr}>\mathrm{Cu}>\mathrm{Ni}>\mathrm{Cd}>\mathrm{Pb}>\mathrm{Zn}>\mathrm{As}$. In crop soils, the coefficients of variation varied from $23 \%$ for $\mathrm{Ni}$ to $49 \%$ for $\mathrm{Cd}$ and decreased in the order $\mathrm{Cd}>\mathrm{Cu}>\mathrm{Pb}>\mathrm{As}>\mathrm{Zn}>\mathrm{Cr}>\mathrm{Ni}$. The relatively low coefficients of variation and significantly higher concentrations of trace elements in crop soils than in forest and orchard soils, especially for $\mathrm{Cd}, \mathrm{Cu}$ and $\mathrm{Zn}$, suggest nonpoint-source agricultural pollution. This pollution may result from extensive use of fertilisers and pesticides (Madrid et al., 2002; Rodriguez Martin et al., 2006; Sun et al., 2010; Ungureanu et al., 2017; Xiang et al., 2018).

The mean concentrations of $\mathrm{As}, \mathrm{Cr}, \mathrm{Ni}$ and $\mathrm{Pb}$ in peri-urban soils were lower than background values of Ningbo (Fig. 2), indicating that the anthropogenic inputs of these elements were relatively low. This finding in agreement with that of Wei and Yang (2010) that $\mathrm{Cr}$ and $\mathrm{Ni}$ appeared to be relatively less contaminating elements in China (Sun et al., 2013). The mean concentrations of $\mathrm{Cu}, \mathrm{Cd}$ and $\mathrm{Zn}$ in crop soils were 2.9, 1.9 and 1.7 times higher than those concentrations in forest and orchard soils (Fig. 2, Table S2). The significantly $(P<0.01)$ high concentrations of $\mathrm{Cu}, \mathrm{Cd}$ and $\mathrm{Zn}$ indicate a enrichment from agricultural inputs. This finding is in accordance with previous studies (Chen et al., 2008b; Lu et al., 2012; Micó et al., 2006; Wei and Yang, 2010).

For cropland, despite the main agricultural sources for $\mathrm{Cd}, \mathrm{Cu}$ and $\mathrm{Zn}$, some outliers for them may be partly attributed to the field burning, waste dump or other anthropogenic activities in the peri-urban area in Ningbo (Shi and Ganne, 2009; Zhu et al., 2017a). For forest soils, the top outliers for $\mathrm{As}, \mathrm{Cd}, \mathrm{Cu}$ and $\mathrm{Pb}$ shown in Fig. 2 were located mainly in nearby agricultural areas (less $200 \mathrm{~m}$ ) (Fig. S1), indicate that the outliers may be caused by anthropogenic activities in agricultural areas (Madrid et al., 2002; Rodriguez Martin et al., 2006; Shi and Ganne, 2009; Ungureanu et al., 2017). The outliers of $\mathrm{Cr}$ and $\mathrm{Ni}$ in forest and orchard soils found in this study (Fig. 2, Fig. S1) may be caused by point pollution by anthropogenic activities, such as the local 
field burning, the waste dumping and the nearby road dust $(17 \mathrm{~m}$ and $50 \mathrm{~m}$ away from mountain road) (Sun et al., 2010), because widespread contamination with $\mathrm{Cr}$ and $\mathrm{Ni}$ has been reported in road dust (Wei and Yang, 2010).

\subsection{Inter-relationship and source identification}

\subsubsection{PCA}

PCA loading plot for trace elements, macro elements and basic soil properties in peri-urban soils is shown in Fig. 3. Almost all forest and orchard soils were clustered on the left, indicating that the samples were less contaminated than crop soils. In contrast, almost all crop soils were located on the right, which suggests trace elements enrichment. Two forest soils in the upper left quadrant had high $\mathrm{Cr}$ and $\mathrm{Ni}$ concentrations, which may attribute to point pollution by anthropogenic activities, such as the local field burning, the waste dumping and the nearby road dust (Sun et al., 2010). $\mathrm{Cd}, \mathrm{Cu}$ and $\mathrm{Zn}$ line angles were sharp and strongly related to the first axis, indicating that they likely had the same above-mentioned agricultural sources. The $\mathrm{Cr}$ and $\mathrm{Ni}$ distribution differed from those of other trace elements, and the mean $\mathrm{Cr}$ and $\mathrm{Ni}$ concentrations were low (Fig. 2), indicating that $\mathrm{Cr}$ and $\mathrm{Ni}$ were predominantly controlled by the parent material and paedogenic processes, which is consistent with the findings of previous studies (Chen et al., 2008b; Kř́bek et al., 2010; Rodriguez et al., 2008; Sun et al., 2013; Zhao et al., 2014).

PCA for trace element concentrations in crop soils and in forest and orchard soils is shown in Table 2. For crop soils, trace elements could be grouped into a two-component model that accounted for $66 \%$ of the total variance. The rotated component matrix showed that As, $\mathrm{Cr}$ and Ni were associated with the first principal component (PC), and the PC2 included $\mathrm{Cd}, \mathrm{Cu}, \mathrm{Pb}$ and $\mathrm{Zn}$. For forest and orchard soils, trace elements were grouped into a three-component model that accounted for $73 \%$ of the total variance. The rotated component matrix showed that 
$219 \mathrm{Cr}$, $\mathrm{Ni}$ and $\mathrm{Pb}$ were associated with the $\mathrm{PC} 1$, and the PC2 included $\mathrm{Cd}$ and $\mathrm{Cu}$, while $\mathrm{As}$ and $\mathrm{Zn}$ belong to PC3. The results in crop soils and in the forest and orchard soils both imply that $\mathrm{Cr}$ and $\mathrm{Ni}$ can be defined as natural components. That $\mathrm{Pb}$ loading of the PCA differed to $\mathrm{Cr}$ and $\mathrm{Ni}$, and concentrations differed in comparison with forest, orchard and crop soils (Table 2), implying $\mathrm{Pb}$ pollution in crop soils. Given the low As concentrations and coefficients of variation in forest and orchard soils, the As may derive mainly from atmospheric deposition. In forest and orchard soils, $\mathrm{Zn}$ had the similar situation with As. But in crop soils, Zn had a significant enrichment and had similar agricultural sources with $\mathrm{Cd}$ and $\mathrm{Cu}$.

\subsubsection{Correlations between different elements and soil properties}

The correlation matrices between different element concentrations are presented in Fig. 4 and Table S3. Significant correlations between $\mathrm{Cr}$ and $\mathrm{Ni}$ were found both in forest and orchard soils $(\mathrm{R}=0.91, P<0.01)$ and in crop soils $(\mathrm{R}=0.77, P<0.01)$ (Fig. 4), these correlations, together with the low mean concentrations, indicated an above-mentioned lithogenic origin (Rodriguez et al., 2008; Sun et al., 2013; Zhao et al., 2014). This finding can also be confirmed by the results of PCA. With the exception of $\mathrm{Zn}, \mathrm{Pb}$ have significantly positive correlations with other trace elements in crop soils. A similar situation occurred for As. Both $\mathrm{As}$ and $\mathrm{Pb}$ have significant correlations with $\mathrm{Cr}$ and $\mathrm{Ni}$ in forest and orchard soils, and significant correlations with $\mathrm{Cd}$ in crop soils (see Fig. S2 in supporting information). The results imply atmospheric deposition induced by fossil fuel combustion may cause the enrichment of As and $\mathrm{Pb}$ in crop soils. It is reported that atmospheric deposition (such as cement, coal and oil combustion dust, metallurgic dust, vehicle exhaust particles) is the main source of $\mathrm{As}$ and $\mathrm{Pb}$ (Duan and Tan, 2013; Scudlark and Church, 1988; Shi et al., 2012; Shotyk et al., 1996; Zheng et al., 2004). This finding can be partly confirmed by the correlation $(\mathrm{R}=0.52, P<0.01)$ between $\mathrm{As}$ with $\mathrm{Pb}$ in crop soils (Fig. 4, Table $\mathrm{S} 3$ ), as both them were dominated by fossil fuel 
combustion in eastern China (Duan and Tan, 2013; Shi et al., 2012). No correlations between

$\mathrm{Zn}$ and $\mathrm{As}$, and $\mathrm{Pb}$ imply the source is not likely the fertilisers. Close correlations between metal $(\mathrm{Cd}, \mathrm{Cu}$ and $\mathrm{Zn})$ concentrations in crop soils suggested these elements had the same or similar pollution sources (Hernandez et al., 2003; Sun et al., 2010). This finding was partly in accordance with previous studies in which $\mathrm{Cd}, \mathrm{Cu}$ and $\mathrm{Zn}$ were found to be related to agricultural pollution in agricultural soils (Chen et al., 2008b; Lu et al., 2012; Micó et al., 2006; Wei and Yang, 2010).

The correlation matrix between the concentrations of trace elements and soil properties (including macro elements) in peri-urban soils is shown in Table 3. Significant negative correlations between trace elements and altitude, and $\mathrm{C} / \mathrm{N}$ indicate the trace element concentrations differed by land use, since forest sites usually located in high altitude (mean altitude, $138 \mathrm{~m}$; range, 19 to $412 \mathrm{~m}$ ) and rich in carbon concentrations (plant litter) and with lower contaminant burdens in contrast to the crop sites (mean altitude, $25 \mathrm{~m}$; range, -3 to 74 m). Altitude was not correlated with As and Ni concentrations, which confirmed that both of them were derived from origin that is supposed to be independent of altitude. The distribution of the $\mathrm{C} / \mathrm{N}$ ratio was similar with the altitude due to the significant positive correlation between them $(\mathrm{R}=0.74, P<0.001)$ (see Table $\mathrm{S} 4$ and Fig. $\mathrm{S} 3$ in supporting information). The correlation results for a specific type of land use showed weak correlation between the concentrations of trace elements and soil properties, especially for the forest and orchard land shown in Table 3. This differed from the significant correlated results derived from packaged all data.

Significant positive correlations between metal $(\mathrm{Cd}$ and $\mathrm{Cu})$ concentrations and $\mathrm{P}$ concentration (Table 3, Fig. 4) in crop soils indicate they have a possible same agricultural origin. Fertiliser application may be the origin, because $\mathrm{P}, \mathrm{Cu}$ and $\mathrm{Cd}$ is closely associated with both inorganic and organic fertilisers, such as application of livestock manure, compost and 
phosphate (Alloway, 2013; Eghball and Gilley, 1999; Gimeno-García et al., 1996; Nicholson

et al., 2003). Calcium was significantly correlated with $\mathrm{Cd}, \mathrm{Cu}$ and $\mathrm{Zn}$ (Table 3, Fig. 4), especially for $\mathrm{Ca}$ and $\mathrm{Zn}$. Close relationship between $\mathrm{Ca}$ concentration and $\mathrm{P}$ concentration ( $\mathrm{R}$ $=0.61, P<0.01$ ) (Fig. 4) suggests $\mathrm{Ca}$ and $\mathrm{P}$ are most likely derived from application of inorganic fertilisers, most likely the calcium phosphate and calcium superphosphate mentioned above. Gimeno-García et al. (1996) evaluated the concentrations of $\mathrm{Cd}, \mathrm{Cu}$ and $\mathrm{Zn}$ in different inorganic fertilisers (urea, calcium superphosphate, iron sulphate and copper sulphate) in rice farming areas and found that calcium superphosphate contained the highest concentrations of $\mathrm{Cd}, \mathrm{Cu}$ and $\mathrm{Zn}$ as impurities. Close relationship between $\mathrm{Ca}$ and $\mathrm{P}$ also implies that both $\mathrm{Ca}$ and $\mathrm{P}$ are effective indicators and factors explaining the variations of $\mathrm{Cd}, \mathrm{Cu}$ and $\mathrm{Zn}$ in periurban soils in Ningbo. Besides, organic fertilisers, such as livestock manure or its derivatives, are usually composted nearby field and used commonly as a soil nutrient source in most of the 2003).

\subsubsection{Pb isotopic composition analysis}

Regression analysis (Fig. 5a) showed a significant linear relationship $\left(R^{2}=0.41, P<0.001\right)$ between $\mathrm{Pb}$ concentration and ${ }^{206} \mathrm{~Pb} /{ }^{207} \mathrm{~Pb}$ ratios. In Fig. 5b, the points of cropland and points of forest and orchard have much overlapping areas. These linear relationship $\left(R^{2}=0.60, P<\right.$ 0.001) suggests that the $\mathrm{Pb}$ in peri-urban soils was mainly derived from a single, widespread source, or mixed origins with similar isotopic compositions, such as anthropogenic aerosols mostly containing coal and oil combustion dust, metallurgic dust, cement (Duan and Tan, 2013; Wang et al., 2000; Zheng et al., 2004). In Fig. 5b, the ${ }^{208} \mathrm{~Pb} /{ }^{207} \mathrm{~Pb}$ and ${ }^{206} \mathrm{~Pb} /{ }^{207} \mathrm{~Pb}$ ratios of 
cropland are located mainly at the lower left, whilst the ratios from forest and orchard soils are located mainly at the upper right, especially for orchards. Given the relatively high $\mathrm{Pb}$ concentration in crop soils in comparison with forest and orchard soils, the differences in $\mathrm{Pb}$ isotope compositions for different land uses suggest the forest and orchard soils is less contaminated than crop soils. This is due to the effect of canopy interception on the atmospheric deposition. Atmospheric deposited elements have been found to be accumulated in the canopy of the forest for several years and can be release to the soil by rainfall and fire (Erel et al., 1997; Ettler et al., 2014; Iverfeldt, 1991; Lindberg, 1989).

The range of $\mathrm{Pb}$ isotopic compositions is consistent with the range of $\mathrm{Pb}$ isotopic compositions of atmospheric deposition. The range of $\mathrm{Pb}$ isotopic composition of crop soils in this study was similar with the range of $\mathrm{Pb}$ isotope ratios of $\mathrm{PM}_{10}$ aerosols in Shanghai (ca. 110 km away from this study area) and air in other area (Chen et al., 2005a; Komárek et al., 2008; Mukai et al., 2001; Zheng et al., 2004). However, the range of $\mathrm{Pb}$ isotopic composition in our peri-urban soils is similar to the range of deep soil $(80-100 \mathrm{~cm})$, while differed from the range of atmospheric deposition reported in Hu et al. (2018)'s study which investigated in peri-urban area of Nanjing City (ca. $330 \mathrm{~km}$ away from this study area). These findings indicated that the $\mathrm{Pb}$ in peri-urban soils of Ningbo city was likely derived from both natural origin and atmospheric deposition. Given the significant positive correlation between $\mathrm{Pb}$ and other (both contaminant and not contaminant) elements in peri-urban soils, the slight enrichment in $\mathrm{Pb}$ in crop soils compared with forest and orchard soils may attribute to atmospheric deposition induced by fossil fuel combustion (Cheng and Hu, 2010; Dach and Starmans, 2005; Sun et al., 2013). Besides, atmospheric deposition could contribute to $\mathrm{As}$ and $\mathrm{Cu}$ enrichments (AlKhashman, 2004; Hernandez et al., 2003; Rodriguez et al., 2008). The Pb ratios of the two outliers in this study are similar to that of vehicle exhaust (unleaded) (Chen et al., 2005a), but the two locations are far from main roads. These two outliers may be attributed to local field 
burning or to fumes from metal smelting due to the similar isotopic compositions (Komárek et

320 al., 2008).

In this peri-urban areas, $\mathrm{Cd}, \mathrm{Cu}$ and $\mathrm{Zn}$ were contaminant elements mainly derived from fertiliser application, and $\mathrm{As}$ and $\mathrm{Pb}$ were possibly influenced by atmospheric deposition. $\mathrm{Hu}$ et al. (2018)'s study suggested that atmospheric deposition along with fertilization were the major sources of heavy metals accumulation, and the relative contribution of atmospheric deposition reaches up to $33.0 \%$ compared with fertiliser application (33.8\%), industrial emission (25.4\%) and soil parent materials (10.8\%) in the peri-urban soils of Nanjing city (also belong to the Yangtze River Delta region). While in our study, the influence of atmospheric deposition is relative weak. A possible explanation is that the two study areas are within a subtropical monsoon climate zone. The prevailing wind directions are southeast in summer, and Ningbo city locates in the southeast of the Nanjing city. These resulted in the different influence of atmospheric deposition at the two study areas. Another study in two contrasting peri-urban areas of Yangtze River Delta Region showed that application of large amounts of cow manure to vegetables had caused an accumulation of $\mathrm{P}, \mathrm{Cu}, \mathrm{Zn}$ and available $\mathrm{Cd}$ in soil (Huang et al., 2006). The common points for above mentioned studies in peri-urban soils in the Yangtze River Delta region are intensive agricultural production, extensive fertiliser application, many types of crops and related rotation patterns to satisfy the increasing food demands from urban areas. Generally, fertiliser application is an important input for elements contaminant $(\mathrm{Cd}, \mathrm{Cu}$ and $\mathrm{Zn})$ in crop soils with effectively indicated by $\mathrm{Ca}$ and $\mathrm{P}$ in this area, but the specific contaminant and indicative elements are depended on the element compose in applied fertilisers.

\section{Conclusions}

The results showed that the soil trace element concentrations differed according to the type 
of land use in peri-urban areas. The mean concentrations of $\mathrm{Cd}, \mathrm{Cu}$ and $\mathrm{Zn}$ in crop soils were significantly higher than their background values of Ningbo and those in forest and orchard soils, i.e., $\mathrm{Cd}, \mathrm{Cu}$ and $\mathrm{Zn}$ are contaminant elements in this peri-urban areas. Despite the contaminant elements, the $\mathrm{Cr}$ and $\mathrm{Ni}$ are dominant via soil formation. Atmospheric deposition may lead to the difference in $\mathrm{As}$ and $\mathrm{Pb}$ concentrations between land uses. Application of fertilisers, calcium phosphate and calcium superphosphate, livestock manure and compost, are the dominant source of pollutants in the peri-urban soils in Ningbo, especially for $\mathrm{Cd}, \mathrm{Cu}$ and

\section{Acknowledgements}

This work was funded by the National Natural Science Foundation of China (No. 41571130064 , No. 41701018), China Postdoctoral Science Foundation (2017M611018), UK NERC Newton Critical Zone funded project NE/N007417/1 and the Youth Innovation Promotion Association of Chinese Academy of Sciences (2018057).

\section{References}

Al-Khashman OA (2004) Heavy metal distribution in dust, street dust and soils from the work place in Karak Industrial Estate, Jordan. Atmos Environ 38: 6803-6812.

Alloway BJ (2013) Sources of heavy metals and metalloids in soils, Heavy metals in soils. 
Springer, pp. 11-50.

Barton D, Hope D, Billett M, Cresser M (1994) Sulphate adsorption capacity and pH of upland podzolic soils in Scotland: effects of parent material, texture and precipitation chemistry. Appl Geochem 9: 127-139.

Bolan NS, Khan M, Donaldson J, Adriano D, Matthew C (2003) Distribution and bioavailability of copper in farm effluent. Sci Total Environ 309: 225-236.

Chen H, Teng Y, Lu S, Wang Y, Wang J (2015) Contamination features and health risk of soil heavy metals in China. Sci Total Environ 512-513: 143-153.

Chen J, Tan M, Li Y, Zhang Y, Lu W, Tong Y, Zhang G, Li Y (2005a) A lead isotope record of Shanghai atmospheric lead emissions in total suspended particles during the period of phasing out of leaded gasoline. Atmos Environ 39: 1245-1253.

Chen J, Tan M, Li Y, Zheng J, Zhang Y, Shan Z, Zhang G, Li Y (2008a) Characteristics of trace elements and lead isotope ratios in PM 2.5 from four sites in Shanghai. J Hazard Mater 156: 36-43.

Chen T, Liu X, Zhu M, Zhao K, Wu J, Xu J, Huang P (2008b) Identification of trace element sources and associated risk assessment in vegetable soils of the urban-rural transitional area of Hangzhou, China. Environ Pollut 151: 67-78.

Chen T, Zheng Y, Lei M, Huang Z, Wu H, Chen H, Fan K, Yu K, Wu X, Tian Q (2005b) Assessment of heavy metal pollution in surface soils of urban parks in Beijing, China. Chemosphere 60: 542-551.

Cheng $\mathrm{H}, \mathrm{Hu}$ Y (2010) Lead (Pb) isotopic fingerprinting and its applications in lead pollution 
studies in China: a review. Environ Pollut 158: 1134-1146.

Cheng S (2003) Heavy metal pollution in China: origin, pattern and control. Environ Sci Pollut R 10: 192-198.

Dach J, Starmans D (2005) Heavy metals balance in Polish and Dutch agronomy: Actual state and previsions for the future. Agriculture, ecosystems \& environment 107: 309-316.

de la Cueva AV, Marchant BP, Quintana JR, de Santiago A, Lafuente AL, Webster R (2014) Spatial variation of trace elements in the peri-urban soil of Madrid. Journal of soils and sediments 14: 78-88.

De Vries W, Vel E, Reinds G, Deelstra H, Klap J, Leeters E, Hendriks C, Kerkvoorden M, Landmann G, Herkendell J (2003) Intensive monitoring of forest ecosystems in Europe: 1. Objectives, set-up and evaluation strategy. Forest Ecol Manag 174: 77-95.

Dong Y, Zheng W, Zhou J (2007) Soil Geochemical Background in Zhejiang (in Chinese). Agro-geological Environment Survey in Zhejiang. Geological Publishing House, Beijing, China.

Duan J, Tan J (2013) Atmospheric heavy metals and arsenic in China: situation, sources and control policies. Atmos Environ 74: 93-101.

Eghball B, Gilley JE (1999) Phosphorus and nitrogen in runoff following beef cattle manure or compost application. J Environ Qual 28: 1201-1210.

Erel Y, Veron A, Halicz L (1997) Tracing the transport of anthropogenic lead in the atmosphere and in soils using isotopic ratios. Geochim Cosmochim Ac 61: 4495-4505.

Ettler V, Konecny L, Kovarova L, Mihaljevic M, Sebek O, Kribek B, Majer V, Veselovsky F, 
Penizek V, Vanek A, Nyambe I (2014) Surprisingly contrasting metal distribution and fractionation patterns in copper smelter-affected tropical soils in forested and grassland areas (Mufulira, Zambian Copperbelt). Sci Total Environ 473-474: 117-24.

Facchinelli A, Sacchi E, Mallen L (2001) Multivariate statistical and GIS-based approach to identify heavy metal sources in soils. Environ Pollut 114: 313-324.

Fu B, Zhuang X, Jiang G, Shi J, Lu Y (2007) Feature: environmental problems and challenges in China. ACS Publications.

Gimeno-García E, Andreu V, Boluda R (1996) Heavy metals incidence in the application of inorganic fertilizers and pesticides to rice farming soils. Environ Pollut 92: 19-25.

Guagliardi I, Buttafuoco G, Cicchella D, De Rosa R (2013) A multivariate approach for anomaly separation of potentially toxic trace elements in urban and peri-urban soils: an application in a southern Italy area. Journal of Soils and Sediments 13: 117-128.

Guo J, Liu X, Zhang Y, Shen J, Han W, Zhang W, Christie P, Goulding K, Vitousek P, Zhang F (2010) Significant acidification in major Chinese croplands. Science 327: 1008-1010.

Hernandez L, Probst A, Probst JL, Ulrich E (2003) Heavy metal distribution in some French forest soils: evidence for atmospheric contamination. Sci Total Environ 312: 195-219.

Hu W, Wang H, Dong L, Huang B, Borggaard OK, Hansen HCB, He Y, Holm PE (2018) Source identification of heavy metals in peri-urban agricultural soils of southeast China: An integrated approach. Environ Pollut 237: 650-661.

Huang B, Shi X, Yu D, Öborn I, Blombäck K, Pagella TF, Wang H, Sun W, Sinclair FL (2006) Environmental assessment of small-scale vegetable farming systems in peri-urban areas 

391-402.

433

Huang S-L, Wang S-H, Budd WW (2009) Sprawl in Taipei’s peri-urban zone: Responses to spatial planning and implications for adapting global environmental change. Landscape Urban Plan 90: 20-32.

Imperato M, Adamo P, Naimo D, Arienzo M, Stanzione D, Violante P (2003) Spatial distribution of heavy metals in urban soils of Naples city (Italy). Environ Pollut 124: 247256.

Iverfeldt $\AA$ (1991) Mercury in forest canopy throughfall water and its relation to atmospheric deposition. Water Air \& Soil Pollution 56: 553-564.

Khai NM, Ha PQ, Öborn I (2007) Nutrient flows in small-scale peri-urban vegetable farming systems in Southeast Asia-A case study in Hanoi. Agriculture, Ecosystems \& Environment 122: 192-202.

Komárek M, Ettler V, Chrastný V, Mihaljevič M (2008) Lead isotopes in environmental sciences: A review. Environ Int 34: 562-577.

Kř́bek B, Majer V, Veselovský F, Nyambe I (2010) Discrimination of lithogenic and anthropogenic sources of metals and sulphur in soils of the central-northern part of the Zambian Copperbelt Mining District: a topsoil vs. subsurface soil concept. J Geochem Explor 104: 69-86.

Li Z, Ma Z, van der Kuijp TJ, Yuan Z, Huang L (2014) A review of soil heavy metal pollution from mines in China: Pollution and health risk assessment. Sci Total Environ 468-469: 
Lindberg SE (1989) Behavior of $\mathrm{Cd}, \mathrm{Mn}$, and $\mathrm{Pb}$ in Forest-Canopy Throughfall. Springer Netherlands, 233-257 pp.

Liu W, Zhao J, Ouyang Z, Söderlund L, Liu G (2005) Impacts of sewage irrigation on heavy metal distribution and contamination in Beijing, China. Environ Int 31: 805-812.

Liu Y, Liu Y, Chen Y, Long H (2010) The process and driving forces of rural hollowing in China under rapid urbanization. Journal of Geographical Sciences 20: 876-888.

Lu A, Wang J, Qin X, Wang K, Han P, Zhang S (2012) Multivariate and geostatistical analyses of the spatial distribution and origin of heavy metals in the agricultural soils in Shunyi, Beijing, China. Sci Total Environ 425: 66-74.

Madrid L, Díaz-Barrientos E, Madrid F (2002) Distribution of heavy metal contents of urban soils in parks of Seville. Chemosphere 49: 1301-1308.

Manta DS, Angelone M, Bellanca A, Neri R, Sprovieri M (2002) Heavy metals in urban soils: a case study from the city of Palermo (Sicily), Italy. Sci Total Environ 300: 229-243.

Meharg AA (2016) Perspective: City farming needs monitoring. Nature 531: S60-S60.

Micó C, Recatalá L, Peris M, Sánchez J (2006) Assessing heavy metal sources in agricultural soils of an European Mediterranean area by multivariate analysis. Chemosphere 65: 863872.

Morton-Bermea O, Hernández-Álvarez E, González-Hernández G, Romero F, Lozano R, Beramendi-Orosco L (2009) Assessment of heavy metal pollution in urban topsoils from the metropolitan area of Mexico City. J Geochem Explor 101: 218-224. 
Mukai H, Machida T, Tanaka A, Vera YP, Uematsu M (2001) Lead isotope ratios in the urban air of eastern and central Russia. Atmos Environ 35: 2783-2793.

Nicholson F, Smith S, Alloway B, Carlton-Smith C, Chambers B (2003) An inventory of heavy metals inputs to agricultural soils in England and Wales. Sci Total Environ 311: 205-219.

Oh GH, Park CR (2002) Preparation and characteristics of rice-straw-based porous carbons with high adsorption capacity. Fuel 81: 327-336.

Ravankhah N, Mirzaei R, Masoum S (2017) Determination of heavy metals in surface soils around the brick kilns in an arid region, Iran. J Geochem Explor 176: 91-99.

Rodriguez JA, Nanos N, Grau JM, Gil L, Lopez-Arias M (2008) Multiscale analysis of heavy metal contents in Spanish agricultural topsoils. Chemosphere 70: 1085-1096.

Rodriguez Martin JA, Arias ML, Grau Corbi JM (2006) Heavy metals contents in agricultural topsoils in the Ebro basin (Spain). Application of the multivariate geoestatistical methods to study spatial variations. Environ Pollut 144: 1001-12.

Scudlark JR, Church TM (1988) The atmospheric deposition of arsenic and association with acid precipitation. Atmos Environ 22: 937-943.

Sheppard D, Claridge G, Campbell I (2000) Metal contamination of soils at Scott Base, Antarctica. Appl Geochem 15: 513-530.

Shi G, Chen Z, Teng J, Bi C, Zhou D, Sun C, Li Y, Xu S (2012) Fluxes, variability and sources of cadmium, lead, arsenic and mercury in dry atmospheric depositions in urban, suburban and rural areas. Environ Res 113: 28-32.

Shi L, Ganne B (2009) Understanding the Zhejiang industrial clusters: Questions and re- 

Initiatives, pp. 239-266.

Shotyk W, Cheburkin AK, Appleby PG, Fankhauser A, Kramers JD (1996) Two thousand years of atmospheric arsenic, antimony, and lead deposition recorded in an ombrotrophic peat bog profile, Jura Mountains, Switzerland. Earth Planet Sc Lett 145: E1-E7.

Simon D (2008) Urban environments: issues on the peri-urban fringe. Annual review of environment and resources 33 .

Singh S, Kumar M (2006) Heavy Metal Load Of Soil, Water And Vegetables In Peri-Urban Delhi. Environ Monit Assess 120: 79-91.

Sun C, Liu J, Wang Y, Sun L, Yu H (2013) Multivariate and geostatistical analyses of the spatial distribution and sources of heavy metals in agricultural soil in Dehui, Northeast China. Chemosphere 92: 517-23.

Sun Y, Zhou Q, Xie X, Liu R (2010) Spatial, sources and risk assessment of heavy metal contamination of urban soils in typical regions of Shenyang, China. J Hazard Mater 174: 455-62.

Teng Y, Wu J, Lu S, Wang Y, Jiao X, Song L (2014) Soil and soil environmental quality monitoring in China: a review. Environ Int 69: 177-199.

Tóth G, Hermann T, Da Silva M, Montanarella L (2016) Heavy metals in agricultural soils of the European Union with implications for food safety. Environ Int 88: 299-309.

Ungureanu T, Iancu GO, Pintilei M, Chicoș MM (2017) Spatial distribution and geochemistry of heavy metals in soils: A case study from the NE area of Vaslui county, Romania. J 
Wang J, Guo P, Li X, Zhu J, Reinert T, Heitmann J, Spemann D, Vogt J, Flagmeyer R-H, Butz T (2000) Source identification of lead pollution in the atmosphere of Shanghai City by analyzing single aerosol particles (SAP). Environ Sci Technol 34: 1900-1905. assessment of metals in urban soils around the Tanggu chemical industrial district, Tianjin, 
Zheng J, Tan M, Shibata Y, Tanaka A, Li Y, Zhang G, Zhang Y, Shan Z (2004) Characteristics of lead isotope ratios and elemental concentrations in PM 10 fraction of airborne particulate matter in Shanghai after the phase-out of leaded gasoline. Atmos Environ 38:

540 1191-1200.

Zheng J, Zhou Z, Wei Y, Chen T, Feng W, Chen H (2018) High-throughput profiling of seasonal variations of antibiotic resistance gene transport in a peri-urban river. Environ Int 114: 87-94. Strategy in China. Springer, pp. 51-72.

Zhu Y-G, Reid BJ, Meharg AA, Banwart SA, Fu B-J (2017b) Optimizing Peri-URban Ecosystems (PURE) to re-couple urban-rural symbiosis. Sci Total Environ 586: 10851090. 